\title{
ANALISIS FRAMING DALAM PEMBERITAAN MEDIA
}

\author{
Muzakkir \\ Program Studi Ilmu Komunikasi FISIP Universitas Teuku Umar \\ Email: muzakkir@utu.ac.id
}

\begin{abstract}
Framing analysis is the latest version of the discourse analysis approach, especially for analyzing media texts. Framing analysis as a method of media content analysis, classified as a new version. It evolved in unison with the views of the constructors. This paradigm has its own position and outlook towards the media. News in the view of social construction, is not an event or fact in a real sense. Here reality is not just simply taken for granted as news. It is a product of interaction between journalists and facts. In the process of internalization of journalists hit by reality. Reality is observed by journalists and absorbed in the consciousness of journalists. In the process of externalization, journalists throw themselves into meaningful reality. Conceptions of facts are expressed to see reality. The result of the news is the product of the process of interaction and dialectics. There are two aspects to framing that, First; pick facts, second; write down facts.
\end{abstract}

Keywords: Framing Analysis, Newspaper Frame, Impact of News

\section{PENDAHULUAN}

Analisis framing merupakan pendekatan untuk melihat bagaimana realitas 'dibingkai' dan dipublikan oleh media. Bagaimana media mengembangkan kasus tertentu atas realitas. Artinya, peristiwa yang sama dapat dikonstruksikan secara berbeda dengan menggunakan frame (bingkai) yang berbeda oleh media.

Ada dua aspek dalam framing yang, Pertama; memilih fakta, kedua; menuliskan fakta. Dalam memilih fakta terkandung dua kemungkinan, apa yang dipilih (bagian berita), apa yang dibuang (bagian mana yang tidak diberitakan). Ini sangat tergantung media bagaimana melihat sisi menarik berita.

Pada dasarnya framing adalah metode untuk melihat cara bercerita (story telling) media atas peristiwa. Cara bercerita itu tergambar pada "cara melihat" terhadap realitas yang dijadikan berita. "Cara melihat" ini berpengaruh pada hasil akhir dari konstruksi realitas. Analisis framing adalah analisis yang dipakai untuk melihat bagaimana media mengkonstruksi realitas.(Eriyanto; 2009). Setiap waktu kita dapat melihat dan membaca bagimana suatu peristiwa yang sama tapi diberitakan secara berbeda oleh media. Contoh, peristiwa yang sama dapat diberi bingkai yang berbeda, kisah nyata berikut ini, pada 1 September 1983, pesawat pembom milik Soviet menembak jatuh pesawat penumpang Korea 007, yang mengakibatkan tewasnya 269 penumpang termasuk awak pesawat. Selang lima tahun kemudian, tepatnya 3 Juli 1988, pesawat penjelajah Amerika, Vincenes, menembak jatuh pesawat penumpang Iran 655 yang melintasi diatas Teluk, dan mengakibatkan tewasnya 290 penumpang termasuk awak pesawat.

Kedua peristiwa tersebut diatas sama, hanya yang berbeda pelakunya; yang pertama Soviet dan yang kedua Amerika. Ternyata peristiwa yang sama tersebut dikonstruksi secara berbeda dalam pemberitaan surat kabar Amerika. Peristiwa tertembaknya pesawat penumpang Korea oleh Soviet digambarkan sebagai suatu pembunuhan atau serangan udara. Liputan pers memakai banyak label dan kata-kata yang mengutuk peristiwa itu sebagai pembunuhan. Kekejaman Soviet diulas dengan liputan yang bertubi-tubi. Akan tetapi, sawaktu memberitakan 
jatuhnya pesawat sipil Iran akibat ditembak pesawat Amerika, liputan Pers Amerika mempunyai gambaran yang berbeda. Penembakan itu tidak digambarkan sebagai pembunuhan, tetapi disebut kecelakaan dalam sebuah tragedy. (Alex Sobur; 2009)

Pendapat lain, analisis framing merupakan salah satu alternatif model analisis yang dapat mengungkap rahasia dibalik perbedaaan bahkan pertentangan media dalam mengungkapkan fakta. Dengan demikian realitas sosial dipahami, dimaknai, dan dikonstruksi dengan bentukan dan makna tertentu. Melalui analisis framing akan dapat diketahui siapa mengendalikan siapa, siapa lawan siapa, mana kawan mana lawan, mana patron dan mana klien, siapa diuntungkan dan siapa dirugikan, siapa menindas dan siapa tertindas, dan seterusnya. Kondisi seperti ini sangat mungkin diperoleh karena analisis framing merupakan suatu seni, kreativitas yang memiliki kebebasan dalam menafsirkan realitas dengan menggunakan teori dan metodologi tertentu.

\section{METODE PENELITIAN}

Tulisan ini memakai metode penelitian analisis teks media dengan mengunakan analisis framing, untuk mengetahui media dalam pembikaian suatu peristiwa baik melalui berita, opini maupun wawancara yang (Eriyanto; 2009). Pendekatan yang digunakan adalah deskriptif kualitatif yang ditujukan untuk mengumpulkan informasi aktual secara terperinci yang melukiskan gejala yang ada, dan mengidentifikasi masalah atau memeriksa kondisi dan praktek yang berlaku.

Selain itu, penulisan ini juga menggunakan discourse analysis (analisis wacana). Analisis wacana berkenaan dengan isi pesan komunikasi. Melalui metode ini, berupaya memberikan gambaran tentang informasi/peristiwa dengan melakukan analisis terhadap berita-berita yang dipublikasikan melalui media.

Metode discourse analysis adalah suatu kajian atau telaah mengenai aneka bahasa yang digunakan secara alamiah. (Alex Sobur; 2009). Dalam pendekatan analisis wacana, kata dan kalimat yang jernih berarti kata dan kalimat yang tidak tersembunyi di balik pemuatan berita. Analisis wacana salah satu alternatif dari analisis isi. Kata alternatif digunakan untuk menunjukkan bahwa analisis wacana dapat melengkapi dan menutupi kelemahan dari analisis isi.

Analisis wacana berkenaan dengan isi pesan komunikasi, yang sebagian diantaranya berita-berita yang termuat di surat kabar. Perkembangan analisis wacana saat ini diarahkan sebagai analisis kritis. Bahasa yang digunakan oleh penguasa atau pemerintah untuk mengatur dan mengendalikan warganya, misalnya menjadi contoh analisis wacana kritis.

Dari segi analisisnya, ciri dan sifat wacana itu dapat dikemukakan:

a. Analisis wacana membahas kaidah-kaidah memakai bahasa di dalam masyarakat (rule of use) b. Analisis wacana merupakan usaha memahami makna tuturan dalam konteks, teks, dan situasi. c. Analisis wacana merupakan pemahaman rangkaian tuturan melalui interpretasi semantik.

d. Analisis wacana berkaitan dengan pemahaman bahasa dalam tindak berbahasa (what is said from what is done)

e. Analisis wacana diarahkan kepada masalah memakai bahasa secara fungsional (functional use of language).(Alex Sobur; 2009)

Untuk mendukung penelitian ini perlu dikuatkan dengan data-data yang dapat diperoleh melalui:

\section{Kajian Pustaka}

Penelitian kepustakaan dilakukan untuk memperoleh bahan-bahan yang memungkinkan untuk dipahami dan dikaji terutama yang berkaitan dengan masalah-masalah yang bersifat teoritis. Cara yang dilakukan dengan membaca, mengkaji dan menelaah tulisan-tulisan melalui referensi yang ada seperti pemberitaan pada surat kabar, dan majalah yang ada relevansinya 
dengan persoalan framing. Disamping itu, juga dilakukan observasi untuk mendapatkan data yang benar dan akurat, dengan informan penelitian sebagai sumber informasi.

\section{Versi Analisis}

Analisis framing merupakan versi terbaru dari pendekatan analisis wacana, khususnya untuk menganalisis teks media. Gagasan mengenai framing, pertama kali dikemukakan Beterson tahun 1955. Pada mulanya, frame dimaknai sebagai struktur konseptual atau perangkat kepercayaan yang mengorganisir pandangan politik, kebijakan, dan wacana, serta yang menyediakan kategori-kategori standar untuk mengapresiasi realitas. Untuk selanjutnya pengertian framing berkembang yaitu diterjemahkan untuk menggambarkan proses penseleksian aspek-aspek khusus sebuah realita oleh media. Dalam ranah studi komunikasi, analisis framing mewakili tradisi yang mengedepankan pendekatan atau perspektif multidisipliner untuk menganalisis fenomena atau aktivitas komunikasi.

Analisis framing sebagai suatu metode analisis isi media, tergolong versi baru. Ia berkembang berbarengan dengan pandangan kaum konstruksionisme. Paradigma ini mempunyai posisi dan pandangan tersendiri terhadap media. Konsep mengenai konstruksionisme diperkenalkan oleh sosiolog interpretatif, Peter L. Beger bersama Thomas Luckman, yang banyak menulis karya dan menghasilkan tesis mengenai konstruksi sosial dan realitas. Berita dalam pandangan konstruksi sosial, bukan merupakan peristiwa atau fakta dalam arti yang riil. Disini realitas bukan hanya dioper begitu saja sebagai berita. Ia adalah produk interaksi antara wartawan dengan fakta. Dalam proses internalisasi wartawan dilanda oleh realitas. Realitas diamati oleh wartawan dan diserap dalam kesadaran wartawan. Dalam proses ekternalisasi, wartawan menceburkan dirinya untuk memaknai realitas. Konsepsi tentang fakta diekspresikan untuk melihat realitas. Hasil dari berita adalah produk dari proses interaksi dan dialektika tersebut.

\section{PEMBAHASAN}

\section{Frame Pemberitaan}

Media merupakan motor penggerak secara aktif yang dapat mengarahkan opini masyarakat (opini publik), bahkan dapat berupa pemberian nilai atas fakta. Bagi media, berita merupakan bingkai (frame) yang membatasi pemahaman pembaca. Melalui serangkaian paragraf di setiap berita, media menyampaikan pesan kepada publik. "Berita adalah jendela dunia". Melalui berita, kita mengetahui apa yang terjadi. Dalam berita, jendela itu yang kita sebut sebagai frame (bingkai)".

Frame adalah sebuah prinsip dimana pengalaman dan realitas yang kompleks tersebut diorganisasi secara subyektif. Lewat frame itu, orang melihat realitas dengan pandangan tertentu dan melihat sebagai sesuatu yang bermakna dan beraturan. Frame media mengorganisasikan realitas kehidupan sehari-hari dan akan ditransformasikan ke dalam sebuah cerita. Analisis framing, kerenanya meneliti cara-cara individu mengorganisasikan pengalamannya sehingga memungkinkan seseorang mengidentifikasi dan memahami peristiwa-peristiwa, memaknai aktivitas-aktivitas kehidupan yang tengah berjalan.

Framing itu pada akhirnya menentukan bagaimana realitas itu hadir di hadapan pembaca. Sebuah peristiwa dapat dilihat dari kecamatan yang berbeda, dan dengan demikian menghasilkan frame yang berbeda pula. Media, karenanya harus dilihat sebagai tempat dimana setiap kelompok yang berkepentingan terhadap suatu isu menampilkan bingkainya masing-masing, misalnya; terkait isu (masalah) penerapan dan penegakan syari'at Islam di Aceh.

Media dan kontruksi realitas wacana media adalah sumber utama pengetahuan, perilaku dan ideologi baik bagi kelompok elit maupun warga negara biasa. Sebagian besar informasi yang berkembang bersumber dari publikasi media massa. Sangat sedikit yang bersumber dari penga 
laman dan perbincangan. Sejarah mencatat dan menunjukkan perkembangan informasi media massa yang sedemikian cepat telah mempengaruhi kehidupan manusia secara signifikan. Media massa juga bisa membantu manusia merumuskan peran mereka dalam kehidupan bermasyarakat. Media massa bahkan mampu mengubah konsep manusia tentang kesenangan dan kehidupan.

Begitu banyak dan cepatnya informasi yang diantarkan media massa kepada manusia, sehingga manusia merasa harus mendefinisikan kepentingan politik, ekonomi, sosial dan budaya mereka dalam waktu singkat. Media massa memiliki peran untuk menonjolkan apa yang hendak ditampilkan. Sebagai media tentunya tidak akan terlepas dari apa yang hendak dibangun oleh redaksi, pada era tranformasi dan globalisasi saat ini seakan-akan umat manusia dihadapkan pada rasa keingintahuan yang tinggi akan sesuatu, misalnya dunia metafisika, informatika, termasuk di dalamnya informasi yang mengimformasikan berbagai aktifitas dari seorang selebritis sebagai figure intertainment.

Menurut Ibnu Hamad, untuk membentuk opini publik, media massa pada umumnya melakukan tiga kegiatan sekaligus. Pertama, menggunakan simbol-simbol politik (language of politic). Kedua, melaksanakan strategi pengemasan pesan (language strategies). Ketiga, melakukan fungsi agenda media (agenda setting fungction

\section{Dampak Pemberitaan}

Sebagai pembaca koran, kita seringkali dibuat bingung - kenapa peristiwa yang satu diberitakan, sementara peristiwa yang lain tidak dberitakan. Kenapa kalau ada dua peristiwa yang sama, pada hari yang sama, media lebih sering memberitakan peristiwa yang satu dan melupakan peristiwa yang lain. Kenapa dalam konflik di Aceh, sisi kekejaman yang banyak diliput dan ditekankan oleh media, sementara sisi tuntutan warga Aceh hilang dalam pemberitaan.

Pada sisi lain, sering ditemukan bagaimana persasaan seseorang keluarga, apakah anak, isteri, yang orangtuanya/suaminya dituduh oleh media telah melakukan tindak asusila atau kriminal, sementara dia belum terbukti bersalah, atau bahkan tidak bersalah sama sekali. Disadari atau tidak, tindakan seperti ini, media telah "terjebak" dan ikut dalam memberitakan tindakantindakan massa dan menulisnya dengan cara menghakimi pula.

Jika diamati secara serius, kita disuguhkan dengan pemberitaan Syari'at Islam yang sering menempatkan masyarakat pada posisi pelaku pelanggaran, dan masyarakat adalah pihak yang paling mudah untuk disalahkan. Kondisi ini, mirip dengan pemberitaan ketika terjadi darurat militer. Selama darurat militer, media cendrung memuat berita-berita tanpa cover both sides, dan hampir tak ada verifikasi atau cek and ricek. Dalam suasana darurat militer, ruang gerak media dibatasi. Pemberitaan dipantau ketat oleh pemilik otoritas, sehingga media hilang independensinya sebagai alat kontrol.

Sebagai contoh, Surat Kabar Kompas dalam pemberitaan darurat militer, ia tampak menonjolkan argument, opini-opini militarism, dan citra yang baik dari keberhasilan pengepungan terhadap GAM. Hal ini bersangkutan tentunya dengan hipotesa Kompas yang menganggap bahwa status Darurat Militer bagi Aceh merupakan kebijakan yang tepat dikarenakan kondisi dan situasi Aceh tidak dapat dikendalikan kecuali dengan cara-cara yang tegas dan tangkas yaitu cara-cara militerisme.(Yunidar; 2009).

Kenapa Kompas dan Republika melakukan pemberitaan yang berbeda-beda, ini ternyata karena frame mereka yeng berbeda-beda pula. Baik Kompas maupun Republika memiliki pandangan yang lain (beda) terhadap alasan dan proses dilaksanakannya operasi Darurat Militer di Aceh. Kompas memiliki pandangan terhadap alasan pemberlakuan status Darurat Militer di Aceh, sebagai upaya pemerintah Indonesia yang tepat dengan pertimbangan kondisi konflik Aceh, dimana GAM telah berani menentang dan mencoreng kewibawaan dan kewenangan pemerintah RI. Melalui elemen tematiknya, pandangan Kompas tampak jelas berpihak pada pemerintah RI dan Penguasa Darurat Militer. 
Judul-judul pemberitaan Kompas hampir seluruhnya merupakan penggambaran serta memuat normalisasi, koherensi fungsional dari proses pelaksana dan kemudian hasil pelaksanaan operasi Darurat Militer, khususnya penghancuran terhadap basis-basis GAM. Kompas tidak memberi porsi yang sama dan seimbang terhadap semua pihak. Komunikator yang kerap dimunculkan selalu dari pihak militer dan sedikit sekali dari pihak GAM maupun masyarakat setempat, meskipun ada satu atau dua orang saja dimunculkan sebagai maksud untuk menggemas berita, sehingga seolah-olah itu merupakan realitas yang riil dan dapat dipertanggungjawab terhadap khalayak ramai. (Yunidar; 2009).

Contoh berita Kompas berikut ini dalam lead-nya:

\section{Evaluasi 4 Bulan Operasi Terpadu, GAM Sudah Lemah}

JAKARTA, KOMPAS - Panglima TNI Jenderal Endriartono Sutarto mengatakan, setelah empat bulan operasi pemulihan keamanan di Provinsi Nanggroe Aceh Darussalam, kemampuan Gerakan Aceh Merdeka sudah jauh menurun. Karena itu, untuk dua bulan ke depan perioritas operasi terpadu akan ditujukan pada operasi kemanusiaan, pemantapan jalannya pemerintahan dan penegakan hukum.(Kompas, 11 November 2003)

Berbeda dengan Kompas, surat kabar Republika memiliki pandangan lain tentang alasan diberlakukannya Operasi Darurat Militer di Aceh. Pandangan Republika tampak jelas lewat skema berita, dimana dari sisi tematiknya, jelas Republika tidak setuju dengan diberlakukannya status Darurat Militer. Dalam teks beritanya terdapat banyak pesan bagi pemerintah Indonesia bahwa kekarasan dan cara-cara militerisme bukanlah cara terbaik baik Aceh, melainkan hal tersebut adalah cara-cara pemerintah lama (Soeharto) yang terbukti hanya membuat rakyat Aceh bertambah menderita.

Republika menggunakan jurnalisme demai dalam tematiknya, pemberitaannya tentang korban-korban operasi Darurat Militer, kemudian juga upaya-upaya untuk memberikan porsi yang seimbang terhadap setiap narasumber dan memberitakan fakta yang sudah ada dilapangan (sudah terbentuk) dengan penggambaran apa adanya, tidak berusaha untuk menonjolkan kutipan yang satu dengan kutipan yang lainnya. selanjutnya Republika juga berusaha agar pihaknya tidak terjebak untuk masuk dalam komflik, sehingga dimanfaatkan oleh salah satu pihak.

Contoh berita Republika berikut ini dalam lead-nya:

\section{“TNI Jangan Abaikan Unsur Kemanusiaan"}

JAKARTA - TNI dan Polri diminta tetap bersikap hati-hati dalam melaksanakan Operasi Darurat Militer di Provinsi Naggroe Aceh Darussalam (NAD). Hal itu mengingat trauma masyarakat terhadap (DOM) terhadap kekuatan militer saat pelaksanaan DOM di Serambi Mekkah masih sangat dalam.

Kompas dan Republika memilih pandangan dan frame yang berbeda dalam melihat masalah dan operasi Darurat Militer di Bumi Cut Nyak Dhien. Melalui skema dan konsep framing dalam teks berita, menyimpulkan jenis pemberitaan Kompas adalah jurnalisme perang. Sementara Republika melakukan jurnalisme damai. (Catatan Murizal Hamzah dalam buku Analisis Framing, Yunidar; 2009)

Sisi berikutnya adalah dampak dari pemberitaan memang dahsyat sekali. Ketika Serambi Indonesia, misalnya memberitakan tentang klaim aliran sesat, yang menjadi sasaran kekerasan masyarakat bukan kepada media, akan tetapi kepada kelompok yang dituduhkan membawa aliran sesat itu. Seperti aliran Millata Abraham yang pernah mencuat di Banda Aceh, dan Bireuen, yang sangat gencar dan pernah diberitakan. Peran pemberitaan Harian Serambi Indonesia yang 
mendapat dukungan langsung dari elemen-elemen masyarakat, dapat diamati pada berita berikut ini:

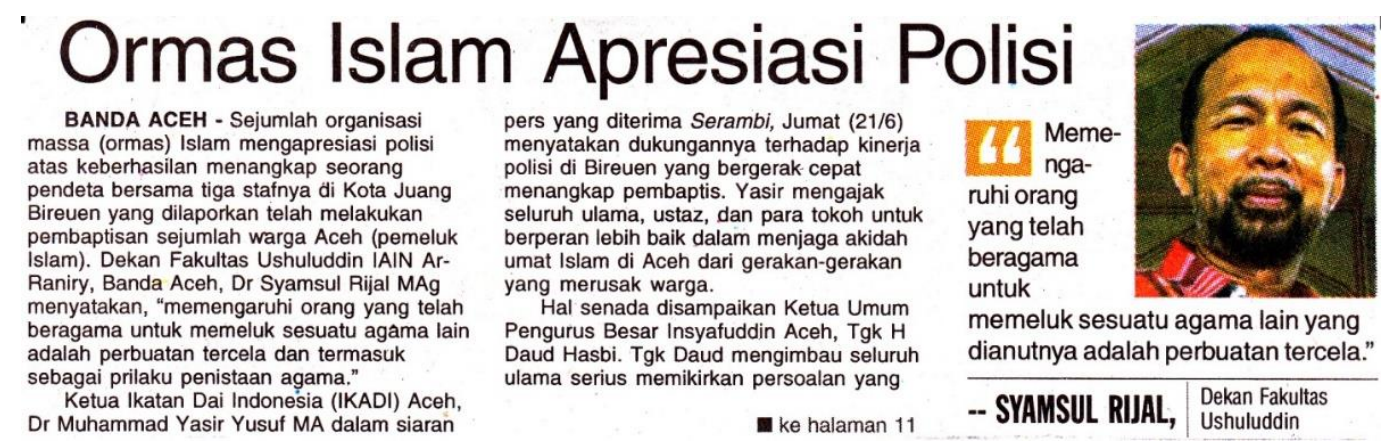

Berita Harian Serambi Indonesia, terbit 22 Juni 2013, hal. 1.

Disatu sisi berita "Ormas Islam Apresiasi Polisi" yang dimuat Harian Serambi Indonesia ini telah memperlihatkan sikap dan tindakan nyata ikut mendukung pemberlakuan Syari'at Islam di Aceh, dengan menunjukkan dukungan positif melalui perannya memberitakan dukungan terhadap penegakan Syari'at Islam dan berkomitmen teguh menjaga aqidah umat. Dukungan itu antara lain datang dari ilmuwan, Prof. Dr. Syamsul Rijal, M. Ag serta dari berbagai elemen masyarakat lainnya.

Namun, disisi lain, dalam berita tersebut Harian Serambi Indonesia, tidak memberi kesempatan bicara kepada si pendeta sebagai pelaku pembaptis warga Aceh, maupun kepada sejumlah warga Aceh yang dilaporkan telah dibaptis. nama-nama mereka yang jadi korban itu, ditulis secara inisial saja, agar terhindar dari amukan massa. Itu perlu dilakukan untuk pembuktian. Kepada warga Aceh yang telah dibaptis itu, ingin didengar suara mereka atau pengakuannya sehingga mereka dengan mudah bisa beralih keyakinan.

Pemberitaan di atas merupakan salah satu bentuk - yang dengan menggunakan 'pisau' analisis framing - media Harian Serambi Indonesia telah berpihak kepada sumber berita selaku penyampai informasi, tidak berusaha menampilkan fakta secara apa adanya. Namun, diberi bingkai (frame) dengan menghasilkan makna yang spesifik, tidak mempertimbangkan prinsipprinsip jurnalisme warga, sebagaimana yang diungkapkan oleh "Bill Kovach dan Tom Rosentiel; kewajiban pertama jurnalisme adalah pada kebenaran, loyalitas pertama jurnalisme kepada warga. Dukungan lainnya terhadap pemberitaan juga terlihat dalam berita berikut ini:

\section{Bersinergi Menegakkan Syari’at Islam}

ANGGOTA DPRK - Banda Aceh, H Iskandar Mahmud SH mengatakan, pelaksanaan Syari'at Islam tidak cukup sekedar patrol petugas Wilayatul Hisbah (WH) dengan menangkap mudamudi bukan muhrim yang berduaan di tempat sepi. Esensi penerapan Syari'at Islam, menurut Ketua Fraksi Daulat Aceh Independen ini, mewujudkan pendidikan yang berkualitas tinggi bagi rakyat. Sebab, kualitas pendidikan merupakan variable penentu berhasil atau tidaknya penerapan Syari'at Islam di Kota Banda Aceh. "Untuk maksud tersebut, Dinas Pendidikan harus bersinergi dengan Dinas Syari'at Islam guna melahirkan suatu formula penegakan Syari'at Islam secara komprehensif, tidak parsial'.'(Berita Harian Serambi Indonesia, terbit 13 Mai 2013, hal 5)

Terkait dengan berita yang dikemas dalam rubrik parlementaria diatas itu, Harian Serambi Indonesia telah melakukan kerjasama dengan wakil rakyat di DPRK Banda Aceh. Tanpa ada kerjasama, berita-berita dari lembaga perwakilan masyarakat tersebut tidak mungkin terekspos dengan baik, sehingga apapun yang dilakukan oleh dewan setempat dalam 
menyuarakan dan memperjuangkan aspirasi masyarakat, tidak akan dapat diketahui oleh masyarakat luas. Oleh karenanya, usaha-usaha Serambi Indonesia juga perlu mendapat apresiasi positif dari semua pihak.

Pendapat dan saran anggota DPRK Banda Aceh tersebut diatas, merupakan dukungan dan sebuah harapan yang murni dalam mendukung penerapan Syari'at Islam di Aceh. Walaupun yang menyampaikan saran dan pendapat itu berprofesi sebagai wakil rakyat. Namun, jika dilihat dari ungkapan dan pemikiran Iskandar Mahmud itu, memang suatu keharusan melakukan kritikan yang konstruktif terutama kepada petugas WH. Karena kenyataan di lapangan selama ini, hanya Satpol PP dan WH yang dikedepankan untuk menangkap warga yang tidak menggunakan pakaian muslimah. Tindakan seperti itu jelas tidak akan membawa perubahan perilaku bagi warga yang melanggar Syari'at Islam. Ada benarnya, apa yang dikatakan Iskandar Mahmud tersebut, bahwa penegakan Syari'at Islam itu harus diutamakan pembinaan budi pekerti dan akhlak yang mulia di sekolah-sekolah mulai pada tingkat TK sampai SMU, melalui mata pelajaran yang permanen di sekolah.

Berita seperti ini, dalam proses framing - sebagaimana kata David Snow adalah upayaupaya strategis secara sadar oleh kelompok-kelompok orang untuk membentuk pemahaman bersama dan mendorong aksi kolektif. "Membentuk pemahaman bersama dan mendorong aksi kolektif" - seperti anjuran wakil rakyat tersebut, "Dinas Pendidikan harus bersinergi dengan Dinas Syari'at Islam guna melahirkan suatu formula penegakan Syari'at Islam secara komprehensif dan secara kaffah”. Kata Iskandar Mahmud dalam berita Harian Serambi Indonesia, terbit 13 Mai 2013, hal. 5.

\section{Landasan Framing dari Perspektif:}

\section{Komunikasi}

Analisis framing dipakai untuk membedah cara-cara atau ideologi media saat mengkonstruksi fakta. Dengan kata lain, framing adalah pendekatan untuk mengetahui bagaimana perspektif atau cara pandang yang digunakan oleh wartawan ketika menyeleksi isu dan menulis berita. Oleh karena itu, berita menjadi manipulatif dan bertujuan mendominasi keberadaan subjek sebagai sesuatu yang legitimate, objektif, alamiah, wajar, dan tak terelakkan.

Sosiologi

Secara sosiologis, konsep frame analysis ialah memelihara kelangsungan kebiasaan kita mengklasifikasi, mengorganisasi, dan menginterpretasi secara aktif pengalaman-pengalaman hidup kita untuk dapat memahaminya. Skemata interpretasi itu disebut frames, yang memungkinkan individu dapat melokalisasi, merasakan, mengidentifikasikan, dan memberi label terhadap peristiwa-peristiwa serta informasi.

Psikologi

Framing dilihat sebagai penempatan informasi dalam konteks yang unik, sehingga elemen-elemen tertentu suatu isu memperoleh alokasi sumber kognitif individu lebih besar. Konsekuensinya, elemen-elemen yang terseleksi menjadi penting dalam mempengaruhi penilaian individu dalam penarikan kesimpulan.

\section{Konsep Analisis Framing}

Konsep tentang framing atau frame sendiri bukan murni konsep ilmu komunikasi, akan tetapi dipinjam dari ilmu kognitif (psikologis). Dalam praktiknya, analisis framing juga membuka peluang bagi implementasi konsep-konsep sosiologis, politik, dan kultural untuk menganalisis fenomena komunikasi, sehingga suatu fenomena dapat diapresiasi dan dianalisis berdasarkan konteks sosiologis, politis, atau kultural yang melingkupinya.

Frame adalah cara bercerita atau gugusan ide-ide yang terorganisir sedemikian rupa dan 
menghadirkan konstruksi makna peristiwa-peristiwa yang berkaitan dengan objek suatu wacana. Berdasarkan konsepnya, Gamson mendefinisikan framing dalam dua pendekatan yaitu: Pendekatan kultural dalam level kultural, frame pertama-tama dapat dimaknai sebagai batasanbatasan wacana serta elemen-elemen konstitutif yang tersebar dalam konstruksi wacana. Dan pendekatan psikologis dalam level individual, individu selalu bertindak atau mengambil keputusan secara sadar, rasional, dan intensional. Individu selalu menyertakan pengalaman hidup, wawasan sosial, dan kecenderungan psikologisnya dalam menginterpretasi pesan yang ia terima.

Menurut Gitlin, Frame sebagai seleksi, penegasan, dan eksklusi yang ketat. Ia menghubungkan konsep tersebut dengan proses memproduksi berita. Konsepsi framing dari para konstruksionis dalam literatur sosiologi ini memperkuat asumsi mengenai proses kognitif individual — penstrukturan representasi kognitif dan teori proses pengendalian informasi-dalam psikologi.

Sedang Entman menyebut, framing dalam dua dimensi besar yaitu seleksi isu dan penekanan atau penonjolan aspek-aspek realitas. Kedua faktor ini dapat lebih mempertajam framing berita melalui proses seleksi isu yang layak ditampilkan dan penekanan isi beritanya. Perspektif wartawanlah yang akan menentukan fakta yang dipilihnya, ditonjolkannya, dan dibuangnya. Di balik semua itu, pengambilan keputusan mengenai sisi mana yang ditonjolkan tentu melibatkan nilai dan ideologi para wartawan yang terlibat dalam proses produksi sebuah berita. Framing memiliki impilkasi penting bagi komunikasi politik. Sebab framing memainkan peran utama dalam mendesakkan kekuasaan politik, dan frame dalam teks berita sungguh merupakan kekuasaan yang tercetak - ia menunjukkan identitas para aktor atau interest yang berkompetisi untuk mendominasi teks.

Konsep framing menurut Entman, secara konsisten menawarkan sebuah cara untuk mengungkap the power of a communication text. Framing analysis dapat menjelaskan dengan cara yang tepat pengaruh atas kesadaran manusia yang didesak oleh transfer informasi dari sebuah lokasi, seperti pidato, ucapan/ungkapan, news report, atau novel. Framing, scara esensial meliputi penseleksian dan penonjolan. Membuat frame adalah menseleksi beberapa aspek dari suatu pemahaman realitas, dan membuatnya lebih menonjol di dalam suatu teks yang dikomunikasikan sedemikian rupa sehinggamempromosikan sebuah definisi permasalahan yang khusus, interpretasi kausal, evaluasi moral, dana atau merekomendasikan penanganannya.

Lalu oleh G.J. Aditjondro juga memberi definisi framing sebagai metode penyaajian realitas dimana kebenaran, tentang suatu kejadian, tidak diingkari secara total, melainkan dibelokkan secara halus, dengan memberikan sorotan terhadap aspek-aspek tertentu saja, dengan menggunakan istilah-istilah yang punya konotasi tertentu, dan dengan bantuan foto, karikatur, dan alat ilustrasi lainnya. Proses framing merupakan bagian tak terpisahkan dari proses penyuntingan yang melibatkan semua pekerja di bagian keredaksian media cetak. Proses framing menjadikan media massa sebagai arena dimana informasi tentang masalah tertentu diperebutkan dalam suatu perang simbolik antara berbagai pihak yang sama-sama menginginkan pandangannya didukung pembaca.

Secara umum terdapat tiga tindakan yang biasa dilakukan pekerja media massa, khususnya oleh komunikator massa, tatkala melakukan konstruksi realitas politik yang berujung pada pembentukan makna atau citra mengenai sebuah kekuatan politik, yaitu:

a. Dalam hal pilihan kata (simbol) politik. Dalam komunikasi politik, para komunikator bertukar citra-citra atau makna-makna melelui lambang. Mereka saling menginterpretasikan pesan-pesan (simbol-simbol) politik yang diterimanya.

b. Dalam melakukan pembingkaian (framing) peristiwa politik. Untuk kepentingan pemberitaan, komunikator massa seringkali hanya menyoroti hal-hal yang "penting" (mempunyai nilai berita) dari sebuah peristiwa politik. Ditambah pula dengan berbagai kepentingan, maka konstruksi realitas politik sangat ditentukan oleh siapa yang memiliki kepentingan (menarik keuntungan atau pihak mana yang diuntungkan) dengan berita tersebut. 
c. Menyediakan ruang atau waktu untuk sebuah peristiwa politik. Justru hanya jika media massa memberi tempat pada sebuah peristiwa politik, maka peristiwa akan memperoleh perhatian dari masyarakat. Semakin besar tempat yang diberikan semakin besar pula perhatian yang diberikan oleh khalayak. Pada konteks ini media massa memiliki fungsi agenda setter sebagaimana yang dikenal dengan teori Agenda Setting.

Perangkat framing dalam pendekatan ini dapat dibagi dalam empat struktur besar, yaitu:

1. Struktur sintaksis merupakan penyusunan fakta atau peristiwa dalam teks berita yang berupa pernyataan, opini, kutipan, pengamatan atas peristiwa, disusun dalam bentuk susunan umum berita. Perangkat framing adalah skema berita, dan unit yang diamati adalah headline, lead, latar informasi, kutipan sumber, pernyataan dan penutup. Struktur sintaksis dapat memberikan petunjuk yang berguna untuk wartawan dalam memaknai peristiwa dan hendak ke mana berita itu akan diarahkan (Nugroho, 1999: 31).

2. Struktur skrip merupakan pengisahan fakta dalam teks berita. Struktur ini melihat strategi dan cara bercerita atau bertutur yang dipakai oleh wartawan dalam mengemas peristiwa ke dalam bentuk berita. Perangkat framing adalah kelengkapan berita dan unit yang diamati melalui $5 \mathrm{~W}+1 \mathrm{H}$. untuk itu, unsur kelengkapan berita ini dapat menjadi penanda framing yang penting, namun jika salah satu unsur kelengkapan berita yang dimiliki wartawan tidak dimunculkan maka akan memperlihatkan penekanan atau penonjolan dan penyamaran terhadap fakta yang ada.

3. Struktur tematik merupakan penulisan fakta atau menuangkan pandangan dalam teks berita terhadap suatu peristiwa berdasarkan proposisi, kalimat atau hubungan kalimat yang membentuk teks secara keseluruhan. Perangkat framing dari struktur tematik ini terdiri dari detail, maksud, nominalisasi, koherensi, bentuk kalimat, dan hubungan kalimat. Struktur tematik sebenarnya merupakan alat analisis untuk melihat bagaimana fakta ditulis, kalimat yang dipakai, serta menempatkan dan menulis sumber ke dalam teks berita secara keseluruhan.

4. Struktur retoris merupakan penekanan fakta dalam teks berita. Perangkat framing yang digunakan adalah leksikon, grafis, metafora, penandaan dengan unit analisis kata, idiom, gambar, foto, dan grafik. Disamping itu unsur leksikon menunjukan pilihan kata dalam suatu kalimat tertentu. Ketika menulis berita dan menekankan makna atas peristiwa, wartawan akan memakai semua strategi wacana itu untuk meyakinkan khalayak pembaca bahwa berita yang dia tulis adalah benar.

\section{Perbedaan karakteristik analisis framing dengan analisis wacana kritis:}

Analisis Framing:

Pusat perhatian analisis framing lebih kepada pembentukan pesan teks. Dalam hal ini melihat bagaimana pesan atau peristiwa dikonstruksi oleh media. Bagaimana wartawan mengkonstruksi peristiwa dan menyampaikannya kepada khalayak pembaca. Konstruksi makna cenderung bersifat simbolis, laten dan pervasif. Teks berita mengandung sejumlah perangkat retoris yang akan berinteraksi dengan memori khalayak dalam proses konstruksi makna. Tujuannya menangkap bentuk konstruksi media terhadap realitas yang disajikan sebagai berita. Kajiannya mengkaji masalah sintaksis, semantik, skrip, tematik, retoris, skema, detail, nominalisasi antarkalimat, kata ganti leksikon, grafis, metafor, pengandaian, dsb.

Analisis Wacana Kritis:

Sedangkan analisis wacana kritis lebih menekankan pada pemaknaan teks yang mengandalkan interpretasi dan penafsiran peneliti. Setiap teks dimaknai secara berbeda dan ditafsirkan secara beragam. Berpretensi memfokuskan pada pesan latent (tersembunyi). Makna 
suatu pesan tidak bisa hanya ditafsirkan sebagai apa yang tampak dalam teks, namun harus dianalisis dari makna yang tersembunyi. Bukan hanya kata, atau aspek isi lainnya yang dikodekan, tetapi struktur wacana yang kompleks pun dapat dianalisis pada berbagai tingkatan deskripsi. Bahkan makna kalimat dan relasi koheren antarkalimat pun dipelajari.

Tidak berpretensi melakukan generalisasi dengan beberapa asumsi. Karena setiap peristiwa pada dasarnya selalu bersifat unik, karena itu tidak dapat diperlakukan prosedur yang sama yang diterapkan untuk isu dan kasus yang berbeda. Tujuannya menggali bagaimana "pemakaian bahasa" dalam tuturan atau tulisan sebagai bentuk praktek sosial, termasuk di dalamnya praktek kekuasaan. Kajiannya mengkaji wacana, ideologi, representasi, struktur, kognisi sosial, teks, konteks, dsb.

\section{Teknik Analisis Framing}

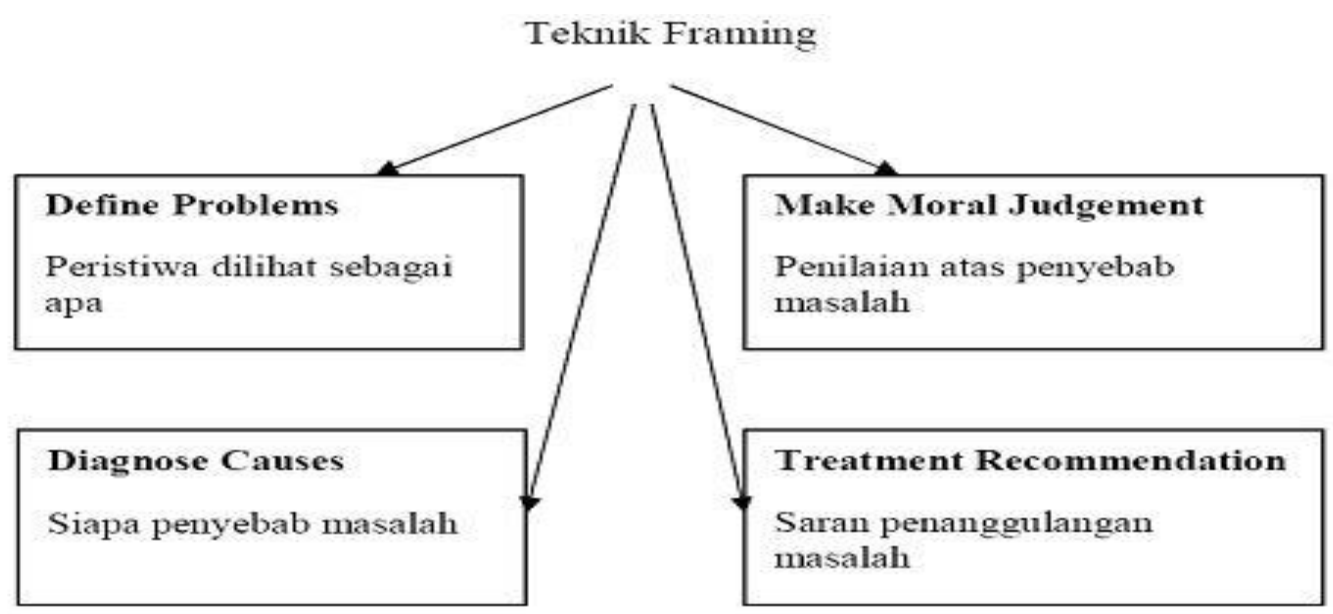

Secara teknis, tidak mungkin bagi seorang jurnalis untuk mem-framing seluruh bagian berita. Artinya, hanya bagian dari kejadian-kejadian penting dalam sebuah berita saja yang menjadi objek framing jurnalis. Namun, bagian-bagian kejadian penting ini sendiri merupakan salah satu aspek yang sangat ingin diketahui khalayak. Aspek lainnya adalah peristiwa atau ide yang diberitakan. Framing dalam berita dilakukan dengan empat cara yaitu: Identifikasi masalah (problem identification), Peristiwa dilihat sebagai apa dan dengan nilai positif atau negatif apa. Identifikasi penyebab masalah (causal interpretation), Siapa yang dianggap penyebab masalah.

Sekurangnya, ada tiga bagian berita yang bisa menjadi objek framing seorang wartawan, yaitu, judul berita, fokus berita dan penutup berita. Judul berita di-framing dengan menggunakan teknik empati yaitu menciptakan "pribadi khayal" dalam diri khalayak, sementara khalayak diangankan menempatkan diri mereka seperti korban kekerasan atau keluarga dari korban kekerasan, sehingga mereka bisa merasakan kepedihan yang luar biasa. Fokus berita di-framing dengan menggunakan teknik asosiasi, yaitu menggabungkan kebijakan aktual dengan fokus brita. Kebijakan yang dimaksud adalah penghormatan terhadap perempuan. Untuk itu, wartawan perlu mengetahui secara persis kondisi riil pencegahan kekerasan terhadap perempuan. Penutup berita di-framing dengan menggunakan teknik packing, yaitu menjadikan khalayak tidak berdaya untuk menolak ajakan yang dikandung berita. Sebab mereka tidak berdaya sama sekali untuk membantah kebenaran yang direkonstruksikan berita.

Menonjolkan Aspek Tertentu-Mengaburkan Aspek Lain. Framing umumnya ditandai dengan menonjolkan aspek tertentu dari realitas. Dalam penulisan sering disebut sebagai fokus. Berita secara sadar atau tidak diarahkan pada aspek tertentu. Akibatnya, ada aspek lainnya yang 
tidak mendapatkan perhatian yang memadai. Menampilkan Sisi Tertentu-Melupakan Sisi Lain. Dengan menampilkan aspek tertentu dalam suatu berita menyebabkan aspek lain yang penting dalam memahami realitas tidak mendapatkan liputan yang memadai dalam berita.

Menampilkan Aktor Tertentu-Menyembunyikan Aktor lain. Berita seringkali juga memfokuskan pemberitaan pada aktor tertentu. Ini tentu saja tidak salah. Tetapi efek yang segera terlihat adalah memfokuskan pada satu pihak atau aktor tertentu menyebabkan aktor lain yang mungkin relevan dan penting dalam pemberitaan menjado tersembunyi.

Mobilisasi Massa. Framing atau isu umumnya banyak dipakai dalam literatur gerakan sosial. Dalam suatu gerakan sosial, ada strategi bagaimana supaya khalayak mempunyai pandangan yang sama atas suatu isu. Itu seringkali ditandai dengan menciptakan masalah bersama, musuh bersama, dan pahlawan bersama. Hanya dengan itu, khalayak bisa digerakkan dan dimobilisasi. Semua itu membutuhkan frame bagaimana isu dikemas, bagaimana peristiwa dipahami, dan bagaimana pula kejadian dimaknai dan didefinisikan.

Menggiring halayak pada ingatan tertentu. Individu mengetahui peristiwa sosial dari pemberitaan media. Karenanya, perhatian khalayak, bagaimana orang mengkonstruksi realitas sebagian besar berasal dari apa yang diberitakan oleh media. Media merupakan tempat dimana khalayak memperoleh informasi mengenai realitas politik dan sosial terjadi di sekitar mereka, Karena itu, bagaimana media membingkai realitas tertentu berpengaruh pada bagaimana individu menafsirkan peristiwa tersebut. Dengan kata lain, frame yang disajikan oleh media ketika memaknai realitas mempengaruhi bagaimana khalayak menafsirkan peristiwa. Membayangkan efek framing pada individu semacam ini, bukan berarti mengandalkan individu adalah makhluk yang menafsirkan realitas politik adalah makluk yang pasif. Sebaliknya, ia adalah entitas yang aktif menafsirkan realitas politik. Pemahaman mereka atas realitas politiik terbentuk dari apa yang disajikan oleh media dengan pemahaman dan predisposisi mereka atas suatu realitas. Hubungan transaksi antara teks dan personal ini melahirkan pemahaman tertentu atas suatu realitas.

\section{Model Analisis Framing.}

Mengoperasionalisasikan empat dimensi struktural teks berita sebagai perangkat framing yaitu, sintaksis, skrip, tematik, dan retoris. Keempat dimensi struktural ini membentuk semacam tema yang mempertautkan elemen-elemen semantik narasi berita dalam suatu koherensi global. Model ini berasumsi bahwa setiap berita mempunyai frame yang berfungsi sebagai pusat organisasi ide. Frame merupakan suatu ide yang dihubungkan dengan elemen yang berbeda dalam teks berita - kutipan sumber, latar informasi, pemakaian kata atau kalimat tertentu-ke dalam teks secara keseluruhan. Frame berhubungan dengan makna. Bagaimana seseorang memaknai suatu peristiwa, dapat dilihat dari perangkat tanda yang dimunculkan dalam teks.

Model analisis framing menurut Robert N Entman adalah untuk menggambarkan proses seleksi dan penonjolan aspek tertentu dari realitas oleh media. Framing memberi tekanan lebih pada bagaimana teks komunikasi ditampilkan dan bagian mana yang dianggap penting atau ditonjolkan oleh pembuat teks. Entman melihat framing dalam dua dimensi besar, yaitu seleksi isu dan penekanan atau penonjolan aspek- aspek tertentu dari realitas atau isu. Dalam prakteknya framing dijalankan oleh media dengan menseleksi isu tertentu dan mengabaikan isu yang lain. Serta menonjolkan aspek dari isu tersebut dengan menggunakan berbagai stategi wacana, misalnya isu ditempatkan pada headline depan, pengulangan, pemakaian grafis untuk mendukung dan memperkuat penonjolan, dan pemakaian label tertentu dan lain sebagainya. Perangkat framing dapat digambarkan sebagai berikut: Seleksi isu. Aspek ini berhubungan dengan pemilihan fakta dari realitas yang kompleks dan beragam, aspek mana yang diseleksi untuk ditampilkan? 


\section{- William A. Gamson dan Andre Modigliani}

Didasarkan pada pendekatan konstruksionis yang melihat representasi media-berita dan artikel, terdiri atas package interaktif yang mengandung makna tertentu. Di dalam package ini terdapat dua struktur, yaitu core frame dan condesnsing symbols. Struktur pertama merupakan pusat organisasi elemen-elemen ide yang membantu komunikator untuk menunjukkan substansi isu yang tengah dibicarakan. Sedangkan struktur yang kedua mengandung dua substruktur, yaitu framing devices dan reasoning devices. Frame merupakan inti sebuah unit besar wacana publik yang disebut package. Framing analysis yang dikembangkan Gamson dan Modigliani memahami wacana media sebagai satu gugusan perspektif interpretasi (interpretatitif package) saat mengkonstruksi dan memberi makna suatu isu.

Pencermatan terhadap interaksi perangkat simbolik (framing devices dan reasoning devices) sebagai dasar digunakannya perspektif. Simbol dalam wacana terlihat transparan bila dalam dirinya menyusup perangkat bermakna yang mampu berperan sebagai panduan menggantikan sesuatu yang lain. Struktur framing devices yang mencakup metaphors, exemplars, catchphrases, depictions, dan visual images menekankan aspek bagaimana "melihat" suatu isu.

Kata Metaphors, cara memindah makna dengan merelasikan dua fakta analogi, atau memakai kiasan dengan menggunakan kata-kata seperti, ibarat, bak, sebagai, umpama, laksana. Metafora berperan ganda; pertama, sebagai perangkat diskursif, dan ekspresi piranti mental; kedua, berasosiasi dengan asumsi atau penilaian, serta memaksa teks membuat sense tertentu.

Menurut Exemplars, mengemas fakta tertentu secara mendalam agar satu sisi memiliki bobot makna lebih untuk dijadikan rujukan/pelajaran. Posisinya menjadi pelengkap bingkai inti dalam kesatuan berita untuk membenarkan perspektif.

Versi Catchpharases, bentukan kata, atau frase khas cerminan fakta yang merujuk pemikiran atau semangat tertentu. Dalam teks berita, catchphrases mewujud dalam bentuk jargon, slogan, atau semboyan. Berbeda dengan Depictions, menggambarkan fakta dengan memakai istilah, kata, kalimat konotatif agar khalayak terarah ke citra tertentu. Asumsinya, pemakaian kata khusus diniatkan untuk membangkitkan prasangka, menyesatkan pikiran dan tindakan, serta efektif sebagai bentuk aksi politik. Depictions dapat berbentuk stigmatisasi, eufemisme, serta akronimisasi.

Sedangkan Visual Images, pemakaian foto, diagram, grafis, tabel, kartun, dan sejenisnya untuk menekspresikan kesan, misalnya perhatian atau penolakan, dibesarkan-dikecilkan, ditebalkan atau dimiringkan, serta pemakaian warna. Visual images bersifat sangat natural, sangat mewakili realitas yang membuat erat muatan ideologi pesan dengan khalayak.

\section{Kesalahan dan Rubrikasi}

Seringkali terjadi kategori yang dipakai dalam mendefinisikan peristiwa itu salah atau menipu khalayak. Peristiwa dibungkus dengan kategori tertentu menyebabkan khalayak tidak bisa menerima informasi sebenarnya. Peristiwa tertentu yang dikategorisasikan dan dibingkai dengan cara tertentu, mempengaruhi bagaimana peristiwa dipahami.

Merupakan salah satu aspek kategorisasi yang penting dalam pemberitaan. Bagaimana suatu peristiwa di kategorisasikan dalam rubrik- rubrik tertentu. Rubrikasi harus dipahami sebagai bagian dari bagaimana fakta diklasifikasikan dalam kategori tertentu. Pendefinisian suatu realitas sosial, secara sederhana dalam strategi pemberitaan dan proses pembuatan berita, dapat dilihat dari bagaimana peristiwa dan fakta di tempatkan dalam rubrik tertentu. Rubrikasi menentukan bagaimana peristiwa dan fenomena harus dijelaskan. Rubrikasi ini bisa jadi miskategorisasiperistiwa yang seharusnya dikategorisasikan dalam satu kasus, tetapi karena masuk dalam rubrik tertentu akhirnya dikategorisasikan dalam rubrik tertentu. Klasifikasi menentukan dan 
memepengaruhi emosi khalayak ketika memandang atau melihat suatu peristiwa. Bagaimana publik mempersepsi realitas dengan bantuan kategori atau klasifiksi yang telah dibuat.

Dalam pandangan Edelman, kategorisasi berhubungan dengan ideologi. Bagaimana realitas diklasifikasikan dan dikategorisasikan, diantaranya ditandai dengan bagaimana kategorisasi tersebut dilakukan. Kategorisasi bukan representasi dari realitas. Pada dasarnya kategorisasi merupakan kreasi kembvali yang penting agar tampak wajar dan rasional, yaitu dengan pemakaian kata- kata terentu yang mempengaruhi bagaimana realitas atau seseorang dicitrakan uang pada akhirnya membentuk pendapat umum mengenai suatu peristiwa atau masalah. Pemakaian bahasa tertentu memperkuat pandangan prasangka, dan kebencian tertentu.

Penonjolan aspek tertentu dari isu. Aspek ini berhubungan dengan penulisan fakta. Ketika aspek tertentu dari suatu peristiwa atau isu tersebut telah dipilih, bagaiman aspek tersebut ditulis? Hal ini sangat berkaitan dengan pemakaian kata, kalimat, gambar, dan citra tertentu untuk ditampilkan pada khalayak. Dalam konsepsi Entman, framing pada dasarnya merujuk pada pemberian definisi, penjelasan definisi, evaluasi dan rekomendasi dalam suatu wacana untuk menekankan kerangka berpikir tertentu terhadap peristiwa yang diwacanakan. Secara lebih jelas dapat digambarkan sebagai berikut:

Model-model framing di atas mempunyai kesamaan, yaitu secara umum membahas mengenai bagaimana media membentuk konstruksi atas realitas, menyajikannya dan menampilkannya kepada khalayak. Model-model tersebut mempunyai beragam cara dan pendekatan. Mengutip Jisuk Woo, paling tidak ada tiga kategori dasar elemen framing. Pertama, level makrostruktural. Level ini dapat dilihat sebagai pembingkaian dalam tingkat wacana. Kedua, level mikrostruktural. Elemen ini memusatkan perhatian pada bagian atau sisi mana dari peristiwa tersebut ditonjolkan dan bagian mana yang dilupakan/dikecilkan. Ketiga, elemen retoris. Elemen ini memusatkan perhatian pada bagaimana fakta ditekankan. Perbandingan di antara model-model tersebut diantaranya; model Entman dan Edelman, tidak merinci secara detil elemen retoris. Meskipun dalam tingkatan analisisnya mereka menunjukkan bagaimana kata, kalimat atau gambar dapat dianalisis sebagai bagian integral memahami frame, tetapi mereka tidak mengajukan gambaran detail mengenai elemen retoris tersebut. Model mereka terutama bergerak pada level bagaimana peristiwa dipahami dan bagaimana pemilihan fakta yang dilakukan oleh media.

\section{KESIMPULAN}

Pemberitaan di Surat Kabar Harian Serambi, Kompas dan Republika dalam menggemas berita berbeda-beda. Kompas dan Republika memilih pandangan dan frame yang berbeda dalam melihat masalah dan Operasi Darurat Militer (DOM) di Bumi Cut Nyak Dhien. Melalui skema dan konsep framing dalam teks berita, menyimpulkan jenis pemberitaan Kompas adalah jurnalisme perang. Sementara Republika melakukan jurnalisme damai.

Media merupakan tempat dimana khalayak memperoleh informasi mengenai realitas politik dan sosial terjadi di sekitar mereka, Karena itu, bagaimana media membingkai realitas tertentu berpengaruh pada bagaimana individu menafsirkan peristiwa tersebut. Dengan kata lain, frame yang disajikan oleh media ketika memaknai realitas mempengaruhi bagaimana khalayak menafsirkan peristiwa.

Selama operasi darurat militer, media cendrung memuat berita-berita tanpa cover both sides, dan hampir tak ada verifikasi atau cek and ricek. Dalam suasana darurat militer, ruang gerak media dibatasi. Pemberitaan dipantau ketat oleh pemilik otoritas, sehingga media hilang independensinya sebagai alat kontrol. 


\section{DAFTAR PUSTAKA}

Alex Sobur. 2009. Analisis Teks Media, suatu pengantar Analisis wacana, Semiotik dan Analisis Framing, Cet. Ke-5, Remaja Rosdakarya. Bandung.

Bil Kovach dan Tom Rosentiel. 2003. Elemen-elemen Jurnalisme, Cet. Ke-2. Institut Studi Arus Informasi. Jakarta.

Eriyanto. 2009. Analisis Framing, Konstruksi, Ideologi, dan Politik Media, Cet. Ke-6, LKiS, Yogyakarta.

Eriyanto, 2009. .Analisisi Wacana, Pengantar Analisis Teks Media, Cet. Ke-7. LKiS. Yogyakarta.

Suf Kasman. 2004. Jurnalisme Universal, Menelusuri Prinsip-prinsip Dakwah Bi Al-Qalam dalam Al-Qur'an, Cet. Ke-1. Teraju Khazanah Keilmuan. Jakarta.

Yunidar. 2009. Analisis Framing Terhadap Pemberitaan Kompas dan Republikan Selama Darurat Militer Di Aceh, Cet. Ke-1. Ar-Rijal Institute. Banda Aceh. 